ISSN: p. 2354-354X e. $2354-3515$

Open Access Journal, Available Online

\title{
Hashtag Activism: Exploring The Church Must Vote Campaign in Nigeria
}

\author{
Temple Uwalaka ${ }^{1}$, Bigman Nwala $^{2} \&$ Confidence Amadi $^{3}$ \\ ${ }^{1}$ University of Canberra, Bruce Campus, ACT 2617, Australia \\ ${ }^{2}$ Ignatius Ajuru University of Education, Port Harcourt, Nigeria \\ ${ }^{3}$ Rivers State University, Port Harcourt, Nigeria \\ temple.uwalaka@canberra.edu.au
}

Received: 2 Feb. 2020 Accepted: 15 May 2020 Date of Publication: June 2020

\begin{abstract}
Socio-political activism and its relationship with digital media diffusion is an on-going subject of considerable debate among observers and scholars globally. This work creates a research trajectory on Nigeria by investigating the contributions of social media in the implementation of The Church Must Vote campaign. It examines the effects of connective action and clicktivism on political mobilization and evaluates how Christians used social media to increase their civic vitality during the 2019 general elections. A total of 6,951 online content, including 42 YouTube videos posted by the users of the hashtag, \#thechurchmustvote, were explored via social networking analysis. Findings show that social media played a significant role in the success of the campaign and served as education channels to advise Christians on the need to participate in the elections. The impressive outcome elicits the recommendation that Nigerians should consider hashtag activism or clicktivism as a valuable political engagement system.
\end{abstract}

Keywords: Clicktivism, social media, hashtag activism, collective action, connective action, Nigerian elections 


\section{Introduction}

The hashtag \#thechurchmustvote represents a campaign in Nigeria by The Church Must Vote (TCMV) - a civil society group. It is a nonpartisan movement of committed Christians aimed at influencing decision making outcomes through participation in the civic process (TCMV, 2019). The two Nigerian co-founders, Ikechukwu Nmor and Peter Smith Obasi, want to enhance the church's civic vitality and make Christians the leading voices in nation-building. This objective could be achieved if Christians were active in the democratic process and ready to uphold their civil rights obligations (TCMV, 2019). The group's strategy is to mobilize voters from around Nigeria by targeting church leaders and members online and on the ground. This approach was demonstrated when the founders announced their intention to rally no fewer than 10 million eligible voters for the country's 2019 general elections to ensure a visible Christian representation (TCMV, 2019). The group created a Facebook group and Twitter handle that have thousands of members. It has considerable traction in Nairaland, a popular online forum dedicated to Nigerians, and has posted several videos on YouTube. Moreover, it has a dedicated website that enunciates its modus operandi and highlights its goals and achievements. The group's significant online presence shows a composite display of the traditional civil society engagements and contemporary online activism.

\section{Problem of the Study}

There are findings in Nigerian digital activism literature suggesting that Nigerians use social media for activism and political participation (Hari, 2014; Uwalaka, 2015, 2017, 2019, Forthcoming; Uwalaka \& Watkins, 2017, 2018; Folayan, et al., 2018). Therefore, it is not surprising that The Church Must Vote group tried to harness Nigerians' innovative use of social media for election mobilization purposes during the 2019 national elections.

The use of digital networks for activism and political participation is a source of debate in political communication and digital activism literature. For example, some scholars remain critical of the role of social media in political participation. White (2010) asserts that online participation is ruining activism, while Fenton and Barassi (2011) argue against the effectiveness of social media use to enhance political participation. Clicktivism has derogatorily been referred to as 'slacktivism' (Kristofferson, White, \& Peloza, 2014), 'micro-political action' (Vromen, 2017, p. 9), 'unproductive, ephemeral' (Gladwell, 2010, 2011), and 
'activism for the lazy' (Morozov, 2009a, p. 1; 2014).

However, the argument exists that contemporary political participation and activism, though carried out at the individual level or even as a solitary action, do benefit political groups, as such political action, though individualistic, are usually situated around a shared concern (Uwalaka, Forthcoming; Halupka, 2014, 2016, 2018; Karpf, 2010). In the case of the Church Must Vote, they are interested in the participation and fair representation of Nigerian Christians in the electoral process. Clicktivism can be conceptualized as a "...low risk, low-cost activity via social media, whose purpose is to raise awareness, produce change, or grant satisfaction to the person engaged in the activity" (Rotman et al., 2011, p. 821). In its purest form, clicktivism maybe just a 'like' on Facebook or a 'share,' 'tweet,' or even a 'retweet' (Halupka, 2014; Karpf, 2010; Lee \& Hsieh, 2013). Due to its online domain and types of activities that characterize it, clicktivism is usually conceived as kit and kin of the logic of connective action. At the center of the logic of connective action, 'is the recognition of digital media as organizing agents' (Bennett \& Segerberg, 2013, p. 34). In this logic, taking action becomes an act of personal articulation and reaction attained by communicating concepts and activities in trusted relationships (Bennett \& Segerberg, 2013).

The use of social media platforms such as Facebook and Twitter and even YouTube videos by Nigerian youths to galvanize the voting population during the last election campaign has hugely been understudied in the study of digital activism and political mobilization in Nigeria. Invisible in all of this is a study that interrogates the contributions of innovative use of social media to the success of The Church Must Vote, a campaign that targets about 50 percent of the voting population in Nigeria. Researchers (Hari, 2014; Kombol, 2014; Uwalaka, 2017, 2019; Uwalaka, Rickard, \& Watkins, 2018) have studied the use of internet in social movement in Nigeria and the use of the internet for political participation. However, invisible are studies that evaluate the use of the internet and its technologies for mobilization during the election by a religious civil society group. Some studies have looked at how internet use has helped in monitoring elections in Nigeria (Bailard \& Livingston, 2014; Uwalaka \& Amadi, 2016), but none have studied specific groups' use of social media infrastructure for election mobilization. This paper is an 
attempt to bridge that gap and to extend the theorization of clicktivism.

\section{Research Questions}

This paper interrogates the effect of connective action in political mobilization in Nigeria by evaluating how Christians in Nigeria used social media to boost The Church Must Vote (\#thechurchmustvote) campaign during the 2019 national election in Nigeria. Consequently, this paper sought to answer the following research questions:

1. What is the effect of social media use to \#thechurchmustvote campaign during the 2019 national elections in Nigeria?

2. What are the themes of social media content regarding the \#thechurchmustvote campaign in Nigeria?

\section{Rationale for the Study}

This study can bridge the gap in digital activism and political communication literature in three specific ways. First, it helps to test the novel logic of connective action theory with empirical data. At the nucleus of the logic of connective action, "is the recognition of digital media as organizing agents" (Bennett \& Segerberg, 2013, p. 34). In this logic, taking action becomes an act of personal expression and acknowledgment attained by communicating concepts and activities in trusted relationships (Bennett \& Segerberg, 2013). Results from this study will lend its voice to the debate relating to this theory, and especially as it concerns the literature in Nigeria.

Second, many of the existing studies about clicktivism are either studied in legacy democracies or autocratic regimes. Consequently, overlooking the unique case of nascent democracies such as Nigeria is contestable. A communication hypothesis or theory is inadequate without being tested in all possible scenarios and backgrounds. This study interrogates the influence of clicktivism in Nigeria as a means of ascertaining the validity of the claims made by scholars (e.g., Halupka, 2018) while espousing the prominence of clicktivism in the modern political process.

Third, this study utilizes an innovative research design to study a new research problem. The study adopts social networking analytic technique to evaluate contents from a Nigerian religious civil society group. This analytic technique used in this study introduces communication scholars to social networking analysis research design.

\section{Literature Review}

This literature review section concentrates on social media and 
political engagement, and how it relates to the study at hand. It also appraises the logic of collective and connective actions.

\section{Social media and Political}

\section{Participation}

Existing literature in political communication holds that the 'political' is intrinsically bound to traditional modes of political engagement (Hirst, 1999; Schmitt, 2008). The 'political' is usually voting, government, democracy, political parties, and legislature. These are traditional approaches to political participation and are considered as the arena definition of politics. The definition is in contrast to a process definition of politics which sees politics 'occurring more broadly in society, both within and outside formal institutions and processes' (McCaffrie \& Marsh, 2013, p. 114). Marsh and colleagues (Marsh \& Akram, 2015; McCaffrie \& Marsh, 2013) support a broader definition of political participation. To them, a process definition of politics is required to understand the changing nature of political participation occasioned by innovation in internet technologies, a view also supported by Omojola (2009). A process definition of politics and political participation recognizes that contemporary political participation has diversified in terms of 'agencies, the repertoires, the targets' (Norris, 2002, pp. 215216) and also acknowledges other popular forms of political participation that is not within the political arena. A process definition of politics and political participation accepts the use of memes, social buttons and social media to engage in political participation. One example of this type of political participation is clicktivism. Here, people engage in small, impulsive, non-ideological, political actions such as clicking a like on Facebook, in an attempt to bring about social change through raising of awareness (Halupka, 2014; Karpf, 2010; Kristofferson et al., 2014).

There are increasingly forms of political participation that are underpinned by engagement norms rather than duty norms (Bang, 2011). As such, the emphasis is on engaging with particular problems rather than taking action, which is ideologically driven. A process definition of politics permits researchers to recognize action based on engagement norms, which at some stage spill into the political arena, as another way to participate in politics. More importantly, a process definition of politics and political participation understands and acknowledges the changing nature of society, given that the internet has helped unfasten citizens from their political groups. 
This development has empowered these citizens to seek political change on their own, engaging on their terms and in their ways (Halupka, 2016).

However, these changes in political engagement norms have forced critics of the process definition of politics and political participation to argue that process definition will lead to a 'study of everything' as politics and 'every action' political participation (Hirst, 1999; Schmitt, 2008,). Also, Hay (2014) argues that the engagement pattern of process definition of politics and political participation marginalizes the political arena, thereby undermining the arena-based definition of politics and democracy. The above critique is flawed by a narrow focus, evaluating the relationship between acts of clicktivism and the desired political outcome in isolation (Dennis, 2019). By conceptualizing participation as a process, a new set of questions emerge regarding the value of social media as a tool for deepening knowledge, for public discussions and action (Dennis, 2019). Based on the foregoing, scholars have warned that clicktivism should not be written off as an ineffective feelgood tool that young people utilize but rather as a legitimate form of social and political action (Piat,
2019). It has been demonstrated that online petition creation and signing play an essential role in citizen's engagement in politics (Bosch \& Mutsvairo, 2017; Halpin, Vromen, Vaughan, \& Raissi, 2018; Leijendekker \& Mutsvairo, 2014; Mutsvairo, 2013; Mutsvairo \& Sirks, 2015). The argument also exists that the educational potential of online social media groups helps members deepen their understanding of democracy and confidence to take action (Schroeder, Currin, Washington, Curcio, \& Lundgren, 2019) and that clicktivism helps participants in their political and civic engagements (Literat \& Markus, 2019). Hashtag activism or clicktivism has also been argued to be used to express popular internet culture, resistance, and solidarity during crisis events such as terror or to participate in a protest. For example, scholars have noted how "Brussels will land on its feet like a cat' memes during the terror attack in Brussels, Belgium, presented a forum for solidarity building that helped the people to overcome fear (Jensen, Neumayer, \& Rossi, 2020). Others (Hari, 2014; Ibrahim, 2013; Uwalaka et al., 2018) have noted how clicktivism helped educate and motivate Nigerians during the 2012 Occupy Nigeria protest. In all of these, it is visible that rather than reduce political 
participation as anticipated by its critics, clicktivism or digital activism enhances and broadens political participation and engagement.

\section{Theoretical Framework}

This study's theoretical anchors are the Logic of Connective Action and Clicktivism. The logic theory, proffered by Bennett and Segerberg in 2012, contends that the rise of a personalized digitally networked politics in which various individuals address the common problems of their time usually comes from a contentious political perspective. According to its coiner, White Micah (2010), the key tenet of clicktivism is that it is the process of equating political power with clicks. These theories have led to fierce debate in political communication.

The debate about the logic that necessitates collective action is one that has evolved as digital technologies evolve. On the one hand, are scholars who believe in the logic of collective action. They argue that a collective action capable of impacting political participation has to be a joint enterprise, involving the development of strong, thick, deliberative ties between participants (Hay, 2007; Stoker, 2006). Hay and Stoker, and some communication and digital activism scholars (Gladwell, 2010, 2011; Morozov, 2009a, 2009b, 2014; Putnam, 2000) agree that the shift in late-modernity towards the atomization and personalization of politics stands in contrast to the thick collective capacity a healthy democratic system requires. From their perspective, just like those of the arena definition of political participation, the new social trends which prefer thin, loosely organized forms of engagement can be disadvantageous to effective governance, and in many ways, echo the growth of neoliberalism which defends a negative view of the state and its interventionist role.

Bennett and Segerberg (2012, 2013), Bennett, Segerberg, \& Walker (2014), and Segerberg \& Bennett (2011) contend that communication, and the means of communication, can facilitate the development of organizational structures. According to them, communication organizes, and in this way, permits the development of connective action frames. Digitalized technology results in loosely interconnected, interpersonal networks to create outcomes that 'resemble collective action, yet without the same role played by formal organizations or the need for exclusive, collective action framings' (Bennett \& Segerberg, 2013, p. 35). This point is crucial, as it highlights how 
online forms of engagement can reflect the function of their traditional counterparts.

Also, Bennett, Breunig, and Givens (2008) found that personal networks diversity provided a far more cogent explanation for predominantly reliance on digital media than simple association with organizations sponsoring the demonstrations. This means that those who are not 'loyal' to an organization are more likely to use digital media. This has a significant ramification for the logic of connective action. Bennett and colleagues' logic of connective action is similar to the intriguing inquest of other scholars (Bimber, Flanagin, \& Stohl, 2005). Terms such as 'self-organizing groups' and 'private-public lives' are synonymous with Bennett's and colleagues' 'loose networks' and 'personal action frames.' These logics, like the definitions of what is 'political,' are, related but also different.

In contrast to earlier models of submissive citizenship based on a one-way communication managed by authorities, the current generation particularly, young adults, are embracing more expressive styles of actualizing citizenship defined around peer content sharing and social media (Bennett, Wells, \& Freelon, 2011). Therefore, communication aimed at promoting civic engagement is becoming problematic. In an analysis of 90 youth websites operated by diverse civic and political organizations in the United States, results revealed uneven conceptions of citizenship and related civic skills, suggesting that many established organizations are out of step with changing common styles (Bennett et al., 2011).

Also, in proposing the theory of reflexive modernization, Beck and Colleagues (Beck, 1994, 1997; Beck, Giddens, \& Lash, 1994), used the term 'sub-politics' to explain politics beyond those tenets that have been espoused by scholars of collective action type of political participation and political system. In explaining the 'subpolitics' concept, Beck (1997) hinged his argument on the concept of 'individuation.' He believes that through sub-politics, individualism has returned to society. His explanation of individuation aligns not only with the process definition of politics but also to the theory of connective action.

Beck and his colleagues (Beck, 1994, 1997; Beck et al., 1994; Giddens, 1991, 1999) define subpolitics to mean the shaping of society from below. They state that when "viewed from above, this results in the loss of power, the shrinkage and minimization of politics" (Beck et al., 1994, p. 23). 
They argue that in the wake of "sub-politics" (Beck et al., 1994, p. 23), there are growing opportunities to have a share and a voice in the society even for groups hitherto uninvolved in the substantive "technification and industrialization process" (Beck et al., 1994, p. 23). This development brings further opportunities for courageous individuals to "move mountains" in the nerve centers of development (Beck, 1994, p. 23). The rise of sub-politics indicates a weakening of bureaucratic, state-oriented politics, thereby suggesting a tilt towards the process definition of politics or connective action. Giddens' argument about the usefulness of sub-politics critically recount shifts in democracy and political participation. His definition of sub-politics as 'politics that has migrated away from parliament towards singleissue groups in the society' (Giddens, 1999, p. 49) strengthens the arguments that citizens engage in solitary political action that are situated around a common concern. This has helped to stimulate the idea of collective togetherness through comradeships that comes from such participation.

Overall, with evidence from contemporary studies and the changing patterns of political participation, it will be erroneous to perceive politics and political participation as something that happens only in the political arena; neither does it benefit the research community to see it as ubiquitous (Marsh \& Akram, 2015). The need exists to evaluate the relationship between the social and the political carefully. That is the thrust of this paper, particularly as it relates to Nigeria.

\section{Method of the Study}

This study adopted a qualitative content analysis technique (Bryman, 2012, 2016). Specifically, it utilized social media network analytics. According to Khan (2017), this is the art and science of extracting, constructing, analyzing, and understanding social networks. The researcher analyzed tweets and YouTube videos from the hashtag, "\#thechurchmustvote," to ascertain the number of tweets and evaluate the themes from the tweets and videos about the campaign during the period leading to the 2019 general election in Nigeria. Researchers are attracted to social media platforms because they can harvest thousands of content using freely and publicly available and easily configurable tools (Bosch, 2017; Bosch \& Mutsvairo, 2017; Marwick \& Boyd, 2014; Uwalaka \& Watkins, 2018).

A large amount of data that can be gathered from social media platforms has given rise to the use of data science tools to analyze 
"big data" (Marwick \& Boyd, 2014). Researchers are growingly using techniques such as social networking analysis (Bosch, 2017; Literat \& Markus, 2019) to make sense of big data. Hashtags are underrated as a sampling approach in big data analytics (Rafail, 2018), but they remain a powerful system for capturing topic-specific data in social media, particularly on Twitter and Facebook (Bosch, 2017; Jensen et al., 2020; Uwalaka \& Watkins, 2017).

This paper analyzed 6,951 social media contents, including 42 YouTube videos by users of the hashtag, "\#thechurchmustvote." These posts, tweets, and videos were collected between December $1^{\text {st }}, 2018$, to April $30^{\text {th }}, 2019$. Posts and tweets were scraped using Netlytic, while YouTube videos were searched out using the YouTube search function. These posts and tweets were subsequently imported first into an excel and then transferred to an NVivo 12 Pro for analysis. NVivo is a qualitative data analysis software that helps the researcher come up with themes and other relevant trends as well as graphs in qualitative data. The researcher preferred this software because the aim was to develop common themes from the tweets. This method has been used by other studies to analyze their data (Bosch \& Mutsvairo, 2017; Uwalaka \&
Watkins, 2018). The aim here is to categorize users' tweets and retweets as well as posts and comments regarding the \#thechurchmustvote campaign. The videos were described and transcribed verbatim in Microsoft word and copied to NVivo for thematic analysis.

\section{Results}

As stated above, social media (Facebook and Twitter) contents relating to \#thechurchmustvote were analyzed to understand how users phrased their tweets and posts during the 2019 general elections in Nigeria. The total number of tweets and posts analyzed was 6,909. Of these, 4,851 were tweets and retweets, while 2,058 were Facebook posts and comments relating to the hashtag, "\#thechurchmustvote."

Figure 1 and Table 1 below show that of the 4,851 tweets from Twitter and 2,058 comments from Facebook that were analyzed, 41 percent $(2,003)$ of tweets and 35 percent (711) of posts and comments used education and logos themes to communicate to the audience. These tweets utilized logic to convince their followers. It appeared that they were educating their followers with hard data on the need for them to participate in political affairs. These tweets, comments, and even the videos are arguments that appeal to their 
audiences' sense of logic or reason. They cite data, methodically walk through the line of reasoning behind their argument, or precisely recounts historical events relevant to their argument. The logos or education theme is the most popular theme in the tweets, posts, and even the video commentaries that were analyzed.

\begin{tabular}{|l|l|l|}
\multicolumn{3}{|c|}{ Table 1: Themes of Users Posts and Tweets } \\
\hline Themes & $\begin{array}{l}\text { Twitter } \\
\text { n (\%) }\end{array}$ & $\begin{array}{l}\text { Facebook } \\
\text { n(\%) }\end{array}$ \\
\hline Education & $2,003(41)$ & $711(35)$ \\
\hline Orison & $1,200(25)$ & $520(25)$ \\
\hline Impel & $805(17)$ & $407(20)$ \\
\hline Approbation & $670(14)$ & $380(18)$ \\
\hline Others & $173(3)$ & $40(2)$ \\
\hline Total & $4,851(100)$ & $2,058(100)$ \\
\hline
\end{tabular}

For example, in one of the videos analyzed, the narrator said, "did you know that more than 50 percent (90 million) of Nigerians are Christians? 45 million of the 90 million Christians in Nigeria are eligible to vote by age. Yet, we don't see them". Here, the group is playing to the audience's sense of reasoning and using that reason to lure the audience into voting during the election, an instance noted by some authors (Omojola, 2008;
Nelson, Loto and Omojola, 2018, Morah and Omojola, 2018). The narrator ended by using historical data from the United States of America to rouse his audience. $\mathrm{He}$ recalled, "in 2016, Donald Trump won the election in the USA because the majority of evangelical Christians voted for him..." The group here used historical data and statistics to appeal to the logic or reasoning of their audience as a persuasion strategy. 


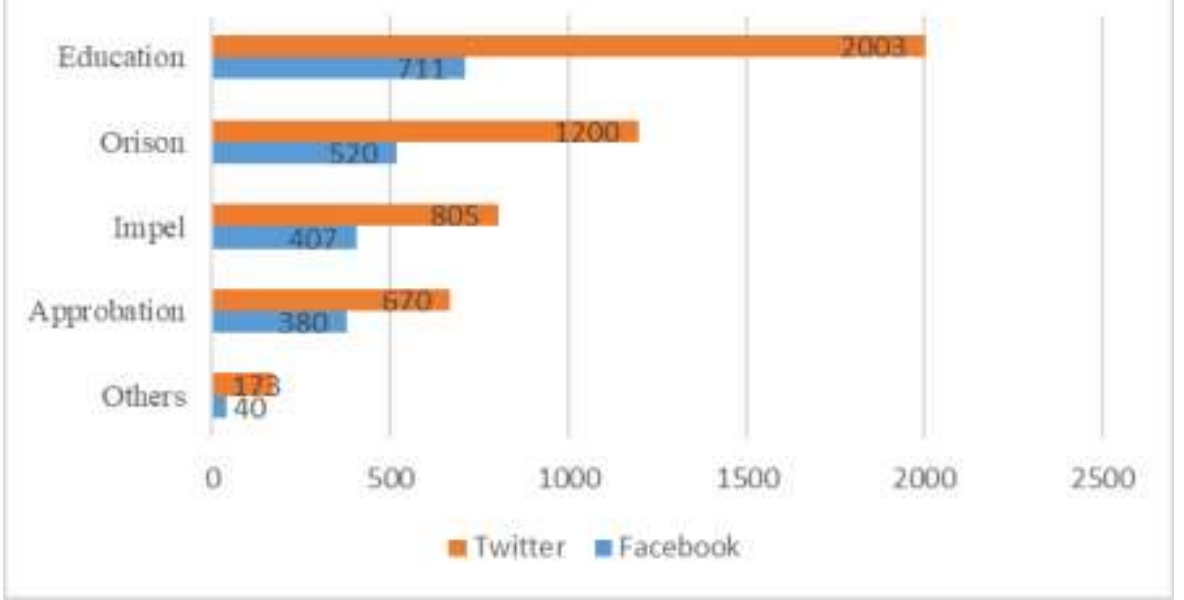

Figure 1: Themes of Users' Posts and Tweets

Of the 4,851 tweets and 2,058 comments analyzed, about 25 percent $(1,200)$ of the tweets, and 25 percent (520) of the comments were prayers. The orison or pathos theme was an essential one as it appealed to the emotion of their audience. Here, social media users tried to persuade their friends and followers by appealing to their emotions. For example, in another video, a narrator prayed:

Father, we pray for every Christian watching us right now that does not have a voter's card. We pray that every spirit of laziness in them dies right now in Jesus Name. Daddy, we pray that every flimsy excuse not to register die right now. We ask that your angels put fire in their heart in the Name of Jesus.

In this video commentary, the narrator used prayer to appeal to the emotions of those watching him who may not have registered to vote. It is meant to scare the audience into taking the desired action. This theme was used a lot by the Church Must Vote group leaders. It is designed to subtly coerce people into registering and collecting their Permanent Voters Card (PVC). Based on data from the previous election cycle, these tactics worked as more people collected their PVC in the Christian states in southeast Nigeria, in 2019 than during previous elections.

Of the 4,851 tweets and 2,058 comments analyzed, 17 percent (805) of the tweets, and 20 percent 
(407) of the comments encouraged Christians to participate in the 2019 elections. The Church Must Vote group leaders based their authority on Christ. They used ethos a lot to persuade their followers to participate in the election. They attempted to appeal to their audience by emphasizing Christ's credibility and authority and why their followers must participate in the election to keep the word of God. For example, a Twitter user used ethos to induce her followers to participate in the election. She notes that

righteousness exalts a nation, and we, the church are the righteousness of God. Therefore, we exalt this nation, Nigeria! It is our responsibility and calling to legislate better leadership in Nigeria. There is a will for change, and there will be change'.

Similarly, another Facebook user admonishes: "don't waste the work of Jesus on the cross. Have you not read the Scripture that says, 'faith without works is dead?'. See, Nigeria does not need $92 \%$. If $50 \%$ of Christians vote for one candidate, that candidate will win the election". Social media users here are trying to encourage their followers to participate in the election using Christ as their credibility source.
Of the 4,851 tweets and 2,058 comments that were analyzed, about 14 percent (670) of the tweets and 18 percent (380) of the comments were tweets and comments of approbation and satisfaction that this time, 'Christians will hold their destiny in their own hands.' This is a crucial aspect of how The Church Must Vote group and their followers approached their mobilization. They believed that their service is celestial and that the gains of participation outweigh the comfort of not participating. The leaders of the group quoted bible passages to buttress their points and usually ascribed their success to divine power. Other times, they predicted that the supernatural would decide the election. For example, one Facebook user posted that, 'in 2019, the vote will be decided not by the cabals, not by the powers that be, but by Jesus'. The Facebook user derided the influence of other factors which she saw as potent, in elections in Nigeria and proclaimed that Jesus Christ would decide the election.

Although the YouTube videos that were analyzed followed similar themes of the tweets and comments and posts, they represented different stages and actors during the campaign. From Figure 2 and Table 2, about 47 percent of the videos were advertisements aired 
online and television. These commercials used logos, pathos, and syllogism to make their case in the videos. These elements helped the video to persuade and mobilize Christians to not only participate in the campaign but also in the elections.

\section{Table 2: Types of YouTube Videos Supporting TCMV}

\begin{tabular}{|l|l|}
\hline Types & $\mathbf{n}(\mathbf{\%})$ \\
\hline Advertising TCMV & $20(47)$ \\
\hline Pastors Reflect about TCMV & $15(36)$ \\
\hline Church Presentation & $5(12)$ \\
\hline Others talk about TCMV & $2(5)$ \\
\hline Total & $42(100)$ \\
\hline
\end{tabular}

Furthermore, 36 percent were selfmade videos, and video remix by famous pastors' speeches about the Church Must Vote campaign. These videos are endorsement videos that are positioned to convince followers of that individual pastor. These videos are about the most-watched videos on Twitter and Facebook. Another 12 percent were videos from leaders of the Church Must Vote groups in churches in Nigeria 'selling' their idea and recruiting new members.

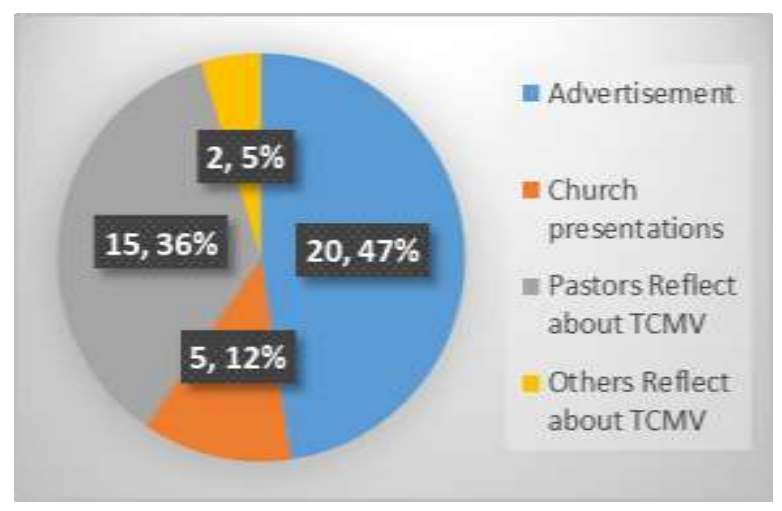

Figure 2: Types of YouTube Videos Analysed

\section{Discussion}

This paper evaluates how Christians in Nigeria used social media to boost the Church Must
Vote

(\#thechurchmustvote) campaign during the 2019 national elections in Nigeria. The paper evaluated themes from the social 
media posts regarding the \#thechurchmustvote campaign in Nigeria, and the influence of social media use during the campaign. Data reveal that the themes coalesced around Christians' education regarding the electoral process. The Church Must Vote campaign group leaders utilized logos to appeal to their followers' principle of reason and judgment by using a lot of statistics to communicate the need for Christians to participate in elections. The leaders also impelled their users and used pathos, that is, emotional appeal to convince their followers to participate in the elections.

The enunciation of themes from the posts, tweets, and videos helped answer research question two
(RQ2). In agreement with previous digital activism studies in Nigeria, social media has been argued to be used to spread enthusiasm and facilitating emotional contagion (Gerbaudo, 2016; Uwalaka, 2016, 2017; Uwalaka \& Watkins, 2017). The use of social media to rouse users' or followers' emotion helped these campaign organizers to tap into users' fears and anger for mobilization. This was used richly during the 2012 Occupy Nigeria protest (Hari, 2014; Uwalaka, 2019; Uwalaka et al., 2018), and during the failed 2015 Social Media Bill in Nigeria (Uwalaka, 2016). Findings reveal that the Church Must Vote campaign group leaders used similar tactics and themes to galvanize their followers, particularly those in the church. 


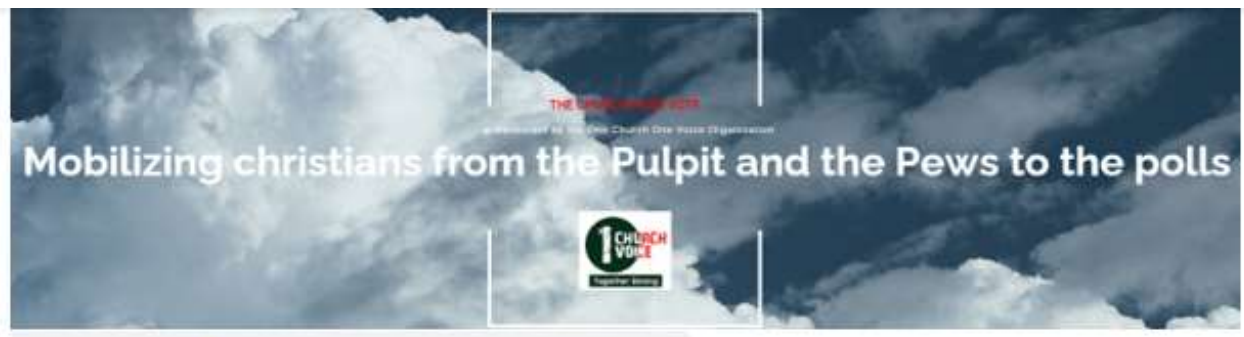

$\leftarrow$ The Church Must Vote

30 1nerts

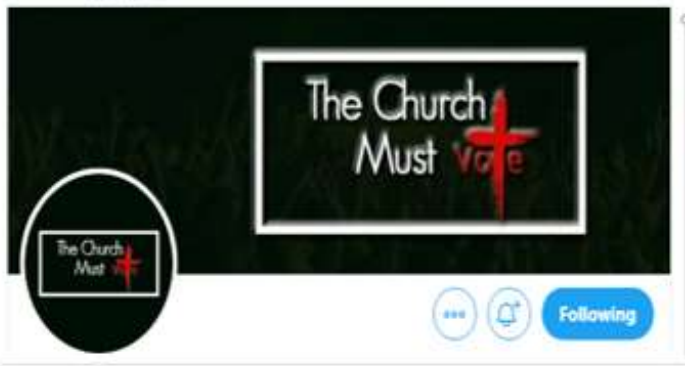

$\leftarrow \quad$ The Church Must Vote

362 Tweets

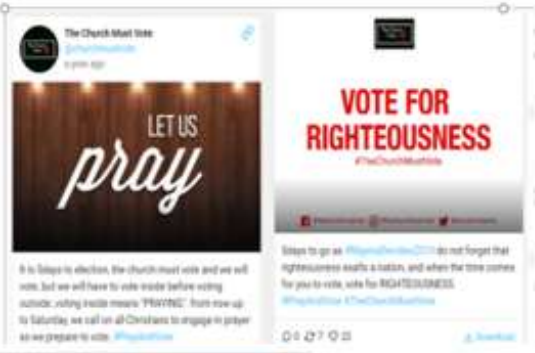

Following

The Church Must Vote @churchmustvote - Feb 24, 2019

Well done Nigerians, we have fought a good fight of faith. Now we wait!l!

*TheChurchMustVote

\#FoughtAGoodFight

Q 2 ᄂ7 4 ○ 25 ث

The Church Must Vote @churchmustvote - Feb 23, 2019

As you go out to vote tomorrow, kindly take clear photos and videos of

incidents at your polling units and send via WhatsApp to us with

08057196644

\#TheChurchMustVote

*VoteYourCibscience

Figure 3: Sample Tweets from TCMV

(Source: The Church Must Vote Twitter Page)

Data further show that social media engagement played a powerful role in not only educating the people but also mobilized them to collect their PVC. This answers the research question one. It also means that social media (Facebook, Twitter, and YouTube), helped the campaign spearheaded by the Church Must Vote, religious civil society group to achieve their goal. This finding suggests that scholars, 
particularly those that espouse arena definition to political participation as well as a collective action, cannot ignore the role of self-organizing groups and the modern way that people participate in politics. This paper argues that it will be difficult to see this new participation style as inauthentic, as is sometimes the case for mainstream analysts, because it does not happen in the political arena, or is not collective in nature. The paper reveals that clicktivism alone cannot bring all the changes that the people desire; it should be a mixture of both clicktivism and organisationally networked civil society groups with stated ideologies. Having said that, results here show that some of these new activism and participation styles such as clicktivism (Halupka, 2014), lead to more visible political action.

This paper reveals the need for scholars to move beyond the differences of the logics and embrace what they have in common as the advancement in communication technology has made it almost impossible to see political participation as something that occurs only in a strong, thick, deliberative ties between citizens; neither does it help to see it as universal. Rather, it should be seen as dualities where one helps the other. Marsh and Akram (2015) made this point when they argued that "connective action and personal action frames are becoming increasingly important, but if citizens are to effect change, this still usually involves collective action" (Marsh \& Akram, 2015, p. 641).

From these findings, this paper argues that clicktivism is legitimate political participation. The findings show that rather than look at the variance in the logic of collective and connective action, researchers should examine their relationship and use that to inform their research. In effect, instead of studying one in isolation of the other, scholars should manage the two logics to see which best describe the result of their study. Bennett and Segerberg (2013) have started this dialogue in their 'when logics collide.' According to them, 'one might expect the ideal types of connective and collective action to appear in pockets, layers, and overlap within the same protest space' (Bennett \& Segerberg, 2013, p. 200). However, it usually is not that linear. It is more symbiotic than is reported in many research studies.

This paper considers the logic of connective and collective action in a continuum. Unlike other scholars, this study argues that when logics collide, it is salient that researchers show where their results lean. For 
example, the results of this study, as well as the nature of the \#thechurchmustvote campaign, show a crossover of 'organizationally brokered networks' and 'organizationally enabled networks' in the typology of collective and connective action network' (Bennett \& Segerberg, 2013, p. 45). When logics collide, this study suggests 'conllective action' to illustrate when a study leans more to connective action and 'collnective action' to represent studies that tilt towards collective action (Uwalaka, Forthcoming). In this study, the logics collided. However, the study leans more to organizationally brokered networks. This means that the study is 'collnective action' than 'conllective action.' Although there were individual users who used individual frames to support the \#thechurchmustvote campaign, the campaign relied heavily on the Church Must Vote's group ideology and thick ties to mobilize the people to participate in the elections.

\section{Conclusion}

This study found common themes from the tweets and posts from Facebook and Twitter. These themes were analyzed based on the data collected. The study found that The Church Must Vote campaign group leaders used logos and pathos to persuade the 'Church' to participate in the elections. They used emotional appeal to stimulate the spirit of togetherness, and of comradeship to achieve the campaign purpose. Based on PVC collection, it can be argued that they were successful.

Clicktivism influences political participation, but it does not supplant the more traditional form of political participation. Clicktivism embodies a vital aspect of all contemporary connective action movements, that is, the fusion of personal views, using personalized action frames, and project-based processes (Halupka, 2018). Irrespective of arena definition of political and participatory legitimacy, connective action more broadly, and clicktivism, in particular, has emerged as a feasible alternative to traditional avenues. Consequently, this study concludes that clicktivism is a legitimate political participation act in that it impacts the political. The study calls for tolerance of both collective and connective actions as both are salient political participation theories. This study notes that both logics are still essential in how people participate in political affairs.

\section{Recommendations}

The following recommendations have been delineated by the researchers as a contribution to 
existing research findings concerning digital activism in Nigeria as well as future connective action studies. This study recommends that,

- hashtag activism or clicktivism be seen as a germane political participation and engagement act.

- Nigerian leaders should vigorously use social media for policy debates, education, and dissemination

- further examination of clicktivism and the logic of

\section{References}

Bailard, C. S., \& Livingston, S. (2014). Crowdsourcing accountability in a nigerian election. Journal of Information Technology \& Politics, 11(4), 349-367.

Bang, H. P. (2011). The politics of threats: late-modern politics in the shadow of neoliberalism. Critical Policy Studies, 5(4), 434448.

Beck, U. (1997). The Reinvention of Politics: Rethinking modernity in the Global Social Order (R. Mark, Trans.). Cambridge: Polity Press.

Beck, U., Giddens, A., \& Lash, S. (1994). Reflexive modernization: Politics, connective action in Nigeria can help to produce a body of research in the area of digital activism and political communication. One area to do this can be to conduct interviews with leaders and participants of campaigns such as the Church Must Vote. This attempt can help in deepening the theorization of connective action and clicktivism. tradition, and aesthetics in the modern social order. Cambridge: $\quad$ Stanford University Press.

Bennett, W. L., Breunig, C., \& Givens, T. (2008). Communication and political mobilization: Digital media and the organization of antiIraq war demonstrations in the US. Political Communication, 25(3), 269289.

Bennett, W. L., \& Segerberg, A. (2012). The logic of connective action: Digital media and the personalization of contentious politics. Information, Communication \& Society, 15(5), 739-768. 
Bennett, W. L., \& Segerberg, A. (2013). The logic of connective action: Digital media and the personalization of contentious politics. New York: Cambridge University Press.

Bennett, W. L., Segerberg, A., \& Walker, S. (2014). Organization in the crowd: peer production in largescale networked protests. Information, Communication \& Society, 17(2), 232-260.

Bennett, W. L., Wells, C., \& Freelon, D. (2011). Communicating civic engagement: Contrasting models of citizenship in the youth web sphere. Journal of Communication, 61(5), 835856.

Bimber, B., Flanagin, A. J., \& Stohl, C. (2005). Reconceptualizing collective action in the contemporary media environment. Communication theory, 15(4), 365.

Bosch, T. (2017). Twitter activism and youth in South Africa: The case of\# RhodesMustFall.

Information, Communication \& Society, 20(2), 221-232.

Bosch, T., \& Mutsvairo, B. (2017). Pictures, protests and politics: Mapping Twitter images during South Africa's fees must fall campaign. African Journalism Studies 38(2), 71-89.

Bryman, A. (2012). Social Research Methods (4th ed.). New York: Oxford.

Bryman, A. (2016). Social research methods. New York: Oxford university press.

Dennis, J. (2019). \#stopslacktivism: Why Clicks, Likes, and Shares Matter. In Beyond Slacktivism (pp. 25-69). Cham, Switzerland: Palgrave Macmillan.

Fenton, N., \& Barassi, V. (2011). Alternative media and social networking sites: The politics of individuation and political participation. The Communication Review, 14(3), 179-196.

Folayan, B.J., Omojola, O., Egharevba, M., Oyesomi, K., Yartey, D \& Adeyeye, B. (2018). The use of ICTrooted communication codes and slangs among Nigerian students. The Journal of Social Sciences Research, 4(12), 633-641.

Gerbaudo, P. (2016). Constructing Public Space| Rousing the Facebook Crowd: Digital Enthusiasm and Emotional Contagion in the 2011 Protests in Egypt and Spain. 
International Journal of Communication, 10, 254273.

Giddens,

A. (1991). The consequences of modernity. Cambridge: Polity Press.

Giddens, A. (1999). The third way: The renewal of social democracy. Cambridge: Polity Press.

Gladwell, M. (2010). Why the revolution will not be tweeted. New Yorker. Retrieved from http://www.newyorker.com/r eporting/2010/10/04/101004f a_fact_gladwell?currentPage =all

Gladwell, M. (2011). From innovation to revolution-do social media made protests possible: An absence of evidence. Foreign Aff., 90, 153-200.

Halpin, D., Vromen, A., Vaughan, M., \& Raissi, M. (2018). Online petitioning and politics: the development of Change.org in Australia. Australian Journal of Political Science, 53(4), 428445.

Halupka, M. (2014). Clicktivism: A systematic heuristic. Policy \& Internet, 6(2), 115-132.

Halupka, M. (2016). The rise of information activism: how to bridge dualisms and reconceptualize political participation. Information, Communication \& Society, 19(10), 1487-1503.

Halupka, M. (2018). The legitimization of clicktivism. Australian Journal of Political Science, 53(1), 130141.

Hari, S. I. (2014). The Evolution of Social Protest in Nigeria: The Role of Social Media in the "\# OccupyNigeria" Protest. International Journal of Humanities and Social Science Invention, 3(9), 33-39.

Hay, C. (2007). Why we hate politics. Cambridge: John Wiley and Sons.

Hay, C. (2014). Depoliticisation as process, governance as practice: what did the'first wave' get wrong and do we need a 'second wave 'to put it right? Policy \& Politics, 42(2), 293-311.

Hirst, P. (1999). Carl Schmitt's Decisionism. In C. Mouffe (Ed.), The Challenge of Carl Schmitt (pp. 7-17). London: Verso.

Ibrahim, B. H. (2013). Nigerians Usage of Facebook during 2012 Occupy Nigeria Protests: a. Between Networked and Real Public Spheres. Science Journal of Researcher, 5(7), 55-64. 
Jensen, M. S., Neumayer, C., \& Rossi, L. (2020). 'Brussels will land on its feet like a cat': motivations for memefying\#

Brusselslockdown.

Information, Communication \& Society 23(1), 59-75.

Karpf, D. (2010). Online political mobilization from the advocacy group's perspective: Looking beyond clicktivism. Policy \& Internet, 2(4), 7-41.

Khan, G. F. (2017). Social media analytics. In Social Media for Government (pp. 93118). Singapore: Springer.

Kombol, M. A. (2014). Uses of Social Media among Selected Labour Unions in Abuja during Nigeria's (January 2012)"Oil Subsidy" Removal Protests. Studies in Media and Communication, 2(1), 102-114.

Kristofferson, K., White, K., \& Peloza, J. (2014). The nature of slacktivism: How the social observability of an initial act of token support affects subsequent prosocial action. Journal of Consumer Research, 40(6), 1149-1166.

Lee, Y., \& Hsieh, G. (2013). Does slacktivism hurt activism? The effects of moral balancing and consistency in online activism. Paper presented at the Proceedings of the SIGCHI Conference on Human Factors in Computing Systems, Paris France.

Leijendekker, I., \& Mutsvairo, B. (2014). On digitally networked technologies, hegemony and regime durability in authoritarian regimes: A Zimbabwean case study. Information, Communication \& Society, 17(8), 1034-1047.

Literat, I., \& Markus, S. (2019). 'Crafting a way forward': online participation, craftivism, and civic engagement in Ravelry's Pussyhat Project group. Information, Communication \& Society, 1-16. DOI: 10.1080/1369118X.2019.157 3910

Marsh, D., \& Akram, S. (2015). In conclusion. Policy Studies, 36(6), 640-643.

Marwick, A., \& Boyd, D. (2014). 'It's just drama': teen perspectives on conflict and aggression in a networked era. Journal of Youth Studies, 17(9), 1187-1204.

McCaffrie, B., \& Marsh, D. (2013). Beyond mainstream approaches to political participation: A response to Aaron Martin. Australian 
Journal of Political Science, 48(1), 112-117.

Morah, D.N. \& Omojola, O. (2018). Social media use and entrepreneurship

development in Nigeria: Lagos and Onitsha in focus.

International Journal of Advance Study and Research Work, 1 (5), 15-26.

Morozov, E. (2009a). From

Slacktivism to Activism. Retrieved from http://neteffect.foreignpolicy. com/posts/2009/09/05/from_ slacktivism_to_activism

Morozov, E. (2009b). Iran:

Downside to the" Twitter Revolution." Dissent, 56(4), 10-14.

Morozov, E. (2014). To save everything, click here: The folly of technological solutionism: PublicAffairs.

Mutsvairo, B. (2013). Power and participatory politics in the digital age: Probing the use of new media technologies in railroading political changes in Zimbabwe. (PhD), Leiden University Institute for History, Faculty of Humanities, Leiden.

Mutsvairo, B., \& Sirks, L. (2015). Examining the contribution of social media in reinforcing political participation in Zimbabwe. Journal of
African Media Studies, 7(3), 329-344.

Norris, P. (2002). Democratic Phoenix:

Reinventing

Political Activism. New York: Cambridge University Press.

Okorie, N., Loto, G. \& Omojola, O. (2018). Blogging, civic engagement, and coverage of political conflict in Nigeria: A study of Nairaland. com. Kasetsart Journal of Social Sciences 39 (2), 291-298.

Omojola, O. (2009). Englishoriented ICTs and ethnic language survival strategies in Africa. Global Media Journal (African Edition), 3 (1). Retrieved May 12, 2020 from https://globalmedia.journals. ac.za/pub/article/view/18.

Omojola, O (2008). Audience mindset and influence on personal political branding. Journal of Social Sciences, 16(2), 124-137.

Piat, C. (2019). Slacktivism: Not simply a means to an end, but a legitimate form of civic participation. Canadian Journal of Family, 11(1), 162-179.

Putnam, R. D. (2000). Bowling Alone: The Collapse and Revival of American Community. New York: Simon \& Schuster. 
Rafail, P. (2018). Nonprobability sampling and Twitter: Strategies for semibounded and bounded populations. Social Science Computer Review, 36(2), 195-211.

Rotman, D., Vieweg, S., Yardi, S., Chi, E., Preece, J., Shneiderman, B., Glaisyer, T. (2011). From slacktivism to activism: participatory culture in the age of social media. In CHI'll Extended Abstracts on Human Factors in Computing Systems (pp. 819-822).

Vancouver,

Canada: ACM.

Schmitt, C. (2008). The concept of the political: Expanded edition. Chicago: University of Chicago Press.

Schroeder, S., Currin, E., Washington, E., Curcio, R., \& Lundgren, L. (2019). "Like, Share, comment," and learn: Transformative learning in online anti-trump resistance communities. Adult Education Quarterly, 70(1), 234-789.

Segerberg, A., \& Bennett, W. L. (2011). Social media and the organization of collective action: Using Twitter to explore the ecologies of two climate change protests. The Communication Review, 14(3), 197-215.
CJOC (2020) 7(1) 1-25

Stoker, G. (2006). Why politics matters: making democracy work. London: Palgrave Macmillan.

TCMV. (2019). The Church Must Vote Retrieved from http://thechurchmustvote.co m/index.php

Uwalaka, T. (2015). Nairaland and the Reconstruction of the Public Sphere in Nigeria. Paper presented at the Australian and New Zealand Communication Association conference:

Rethinking communication, space and identity, Queenstown, New Zealand.

Uwalaka, T. (2016). Muzzling the Fifth Estate: An Analysis of the 2015 'Social Media' Bill in Nigeria. Paper presented at the Australian and New Zealand Communication Association Conference: Creating Space in the Fifth Estate,

Newcastle. https://www.researchgate.net /publication/318671787_Mu zzling_the_Fifth_Estate_An_ analysis_of_the_2015_'Socia 1_Media'_Bill_in_Nigeria

Uwalaka, T. (2017). Mobile Internet and the rise of digital activism among university students in Nigeria. (PhD), University of Canberra, Canberra, Australia. Retrieved from 
http://www.canberra.edu.au/r esearchrepository/file/84213

231-ce41-4573-b0fa4d8008004e96/1/full_text.pd $\mathrm{f}$

Uwalaka, T. (2019). Social media and the rise of digital activism among students in Nigeria. Journal of Communication and Media Research, 11(2), 11-26.

Uwalaka, T. (Forthcoming). Clicktivism and political engagement in Nigeria. The Nigerian Journal of Communication, 17(1).

Uwalaka, T., \& Amadi, C. (2016). Revoda and Election Monitoring in Nigeria. Paper presented at the Australia and New Zealand Communication Association Conference, Creating Space in the Fifth Estate, Newcastle, New South Wales, Australia. https://www.researchgate.net /publication/318671790_Rev oda_and_Election_Monitorin g_in_Nigeria

Uwalaka, T., Rickard, S., \& Watkins, J. (2018). Mobile social networking applications and the 2012 Occupy Nigeria protest. Journal of African Media Studies, 10(1), 3-19.

Uwalaka, T., \& Watkins, J. (2017). Social Media vs. Mainstream Media: An Analysis of the 2012 Occupy Nigeria Protest. In L. Allen (Ed.), 6th Annual International Conference on Journalism \& Mass Communication (pp. 59-68). Singapore: Global Science and Technology Forum.

Uwalaka, T., \& Watkins, J. (2018). Social media as the fifth estate in Nigeria: An analysis of the 2012 Occupy Nigeria protest. African Journalism Studies, 39(4), 22-41.

Vromen, A. (2017). Digital citizenship and political engagement. London:

Palgrave Macmillan.

White, M. (2010). Clicktivism is ruining leftist activism. The Guardian.

http://www.theguardian.com/ commentisfree/2010/aug/12/ clicktivism-ruining-leftistactivism 